\title{
INTESTINAL HELMINTH INFECTIONS AMONG PRIMARY SCHOOL PUPILS IN NIMO COMMUNITY, NJIKOKA LOCAL GOVERNMENT AREA, ANAMBRA STATE, SOUTHEASTERN NIGERIA.
}

\author{
Onyido, A.E ${ }^{1}$., Okoye, M.M²., Irikannu, K.C ${ }^{3 *}$., Okafor, E.N ${ }^{4}$., Ugha, C.N5., Umeanaeto P.U6 ., Egbuche C.M ${ }^{7}$., \\ Iwueze M.O' ${ }^{\mathbf{3}}$ and Ezeani, A.C ${ }^{\mathbf{9}}$. \\ *1,2,3,5,6,7,8,9 Department of Parasitology and Entomology, Nnamdi Azikiwe University, Awka \\ ${ }^{4}$ Department of chemical pathology, University of Nigeria Teaching Hospital, Ituku-Ozala Enugu, Enugu State. \\ *Email: kayceeirika@yahoo.com
}

*Corresponding Author: -

*Email: kayceeirika@yahoo.com

\begin{abstract}
: -
A study to determine the prevalence of intestinal helminth infections among primary school children in Nimo Community, Njikoka Local Government Area, Anambra State, Nigeria was undertaken.

Four Primary Schools, namely Ugwu-Oye Primary School, Unity Primary School, St. Joseph's Primary School and Egbengwu Primary School were involved in the study. 120 pupils were selected from the schools and enlisted into the study. Direct smear and zinc sulphate solution (Flotation method) were used for the isolation of the helminth eggs. Of the 120 stool samples examined, 26(21.7\%) harboured intestinal helminths, Egbengwu Primary School had the highest number of infection 10(33.3\%) and St. Joseph's Primary School had the lowest 3(10.0\%). Intestinal helminth infections observed were hookworms 13(10.8\%), Ascaris lumbricoides 7(5.83\%), Trichuris trichiura 2(1.66\%), Schistosoma mansoni 2 (1.66\%), Strongyloides stercoralis 1(0.83\%) and Taenia spp 1(0.83\%). More females $14(23.3 \%)$ than the males 12(20.0\%) were infected. The age specific prevalence in the four schools was highest in 1316 years age group $3(60.0 \%)$ and least in 5-8 years age group $8(16.0 \%)$. Government schools had higher prevalence of infection $18(30.0 \%)$ than private schools $8(13.3 \%)$. Generally poor sanitation, socio-economic status and ignorance of the epidemiology of infection were related to the prevalence of infection.
\end{abstract}

Keywords: - Intestinal, Helminth, Infections, Nimo, southeastern, Nigeria. 


\section{INTRODUCTION}

Intestinal helminth infections constitute an important public health problem in the tropics. They are among the most prevalent human infections affecting approximately one fourth of the world's population [1]. In developing countries, young women, pregnant women, their infants and children frequently experience a cycle of repeated infections which may lead to adverse consequences that can continue from one generation to another [2].

Helminth infections have been associated with low standard of sanitation and close to one million people are estimated at risk worldwide [3]. In Nigeria, [4] recorded high rates of helminth infections, among people without toilet facilities in Ibadan. Okon and Oku [5] observed that geo-helminths contamination arises from indiscriminate defaecation on the ground, poor hygiene and sanitation. Sociocultural practices such as the use of night soil for fertilizer contributes to the prevalence of intestinal helminth infections [6]. Most helminthic infections are easily contracted through drinking of unboiled faecally contaminated water and through eating of raw or undercooked feacally contaminated vegetables as well as other foods. Due to lack of information or insufficient attention to hygiene, infected individuals may contaminate their water supply with feaces. Some of these parasites are geohelminths, to which children are more exposed to infection and re-infection. For cestode (food-borne helminths), man acquire infection by ingestion of raw or inadequately cooked pork or beef containing the infective larvae (Cysticerci). People are infected with trematode blood fluke, Schistosoma mansoni by contact with water through recreational activities such as swimming or by professional activities such as fishing, rice cultivation and irrigation or socio-economic activities in water bodies with infected host snails.

Although mortality from these parasitic infections may be low, they can cause considerable morbidity. Children's nutritional status are mainly affected leading to malnutrition, growth retardation, anaemia, insomnia, anorexia, hypoproteinemia and some other gastroenteric disturbances [7]. Most infections lead to malnutrition because worms can deplete up to $50 \%$ of the nutrient supply in children, it can also lead to bowel perforation. Children within the age bracket of 1-5 years are always the reservoir group of the nematode parasites because they always play with sand and may not wash their hands after playing and sometimes before eating.

The study was primarily aimed at determining the prevalence of intestinal helminths among primary school pupils in Nimo community in Njikoka Local Government Area, Anambra State. Specifically, the study sought to determine the school and groups (age and sex) mostly affected.

\section{Materials and Methods}

\section{A. Study Area}

The study area is Nimo community in Njikoka Local Government Area, Anambra State, Nigeria. Its geographical coordinates are $6^{\circ} 10^{\prime} 10^{\prime \prime}$ North, $7^{\circ} 0^{\prime} 0^{\prime \prime}$ East. Nimo has four villages which are: Ifite-Enu, Ifite-Ani, Etiti and Egbengwu. The population of the town is about 17,000 [8]. The town is moderately populated with people of various socio-economic classes, including farmers, teachers, civil servants, traders and so on. Almost everybody in the community practice one form of farming or the other, either as occupation or as a supplementary occupation, some have vegetable gardens. They have portable water sources like boreholes, although very few people still prefer stream water for domestic chores like washing of clothes, washing of breadfruit and bitter leaves. Also, some religious groups use stream water for emersion baptism and sacrifices.

\section{B. Selection of Schools of Study}

Four primary schools including two Government owned schools, one private and one missionary school were enlisted for the study. They were; Ugwu-Oye Primary School Etiti, Unity Nursery and Primary School Ifite-Ani, St. Joseph's Nursery and Primary School Ifite-Enu and Egbengwu Nursery and Primary Schools. The private and missionary schools had good toilet facilities (water closet) which were always maintained and their pupils dressed neatly to school, while among the government schools, one has pit toilet and the other has water closet but were not well maintained. Their level of sanitation was poor. Some of the pupils go to school on bare foot or torn sandals which they drag along with them. The children also play around bare-footed during break hours.

\section{Ethical Clearance}

The permission of the individual school authorities was obtained using a letter of introduction from the Head of Department of Parasitology and Entomology, Nnamdi Azikiwe University. Informed consent of the parents and the pupils helped to engender the co-operation and participation of the pupils.

\section{Parasitological Techniques}

Two different parasitological techniques; Direct smear technique and Zinc sulphate floatation technique were used for the analysis of stool samples collected.

\section{E. Direct Smear}

Direct smear method using normal saline described by [9] was employed in the study.

An applicator stick was used to collect about a pin-head size of the properly mixed stool sample and dropped on a microscopic slide which has a drop of normal saline on it. This was emulsified properly, then covered with a cover slip and examined under the microscope using low power objective X10 for the detection of helminths ova or larvae. 


\section{F. Zinc Sulphate Floatation Technique}

An applicator stick was used to collect about 1 gramme of faeces into a test tube, containing 5 drops of zinc sulphate solution, and emulsified properly. The test tube was filled with zinc sulphate and mixed well. The faecal suspension was strained to remove large feacal particles. The suspension was returned to another tube and filled to the brim with the solution. The tube was covered with a grease-free cover-slip, placed in a tube rack and allowed to stand for $45 \mathrm{minutes}$. After the cover slip was removed, placed with the face downwards on a grease-free slide and examined under the microscope using x10 objective.

\section{G. Identification of Helminth Eggs}

The identification of helminth eggs was done using the method described by [10].

\section{Results}

Of the 120 faecal samples examined, 26(21.7\%) were positive with different helminth eggs (table 1). The highest prevalence of helminth infections was observed among the pupils of Egbengwu Primary

School 10(33.33\%) and the least from St. Joseph's Primary School pupils 3 (10.0\%).

Of the 26 pupils positive with geohelminth infections, 13(50.0\%) had hookworm infection, 7(26.9\%) had Ascaris lumbricoides, 2(7.69\%) had either Trichuris trichiura or Schistosoma mansoni respectively while 1(3.84\%) had either Taenia species or Strongyloides stercoralis respectively (Table 2). Ascaris and hookworm infections were prevalent in all the schools studied. Taenia or Strongyloides were found only in one of the schools each. Trichuris and Schistosoma infection were found in two of the schools respectively. More females 14 (23.3\%) than the males $12(20.0 \%)$ had geohelminth infections. However, more males than the females had both Ascaris and hookworm infections, Strongyloides and Taenia were identified in females only. One female was infected by each. An equal number, $(1.66 \%)$ each, were infected with Trichuris or Schistosoma.

The highest geohelminth prevalence of 3(60.0\%) was recorded in the age group 13-16 years while the least $8(16.0 \%)$ was observed in the age group 5-8 years (table 3). Only hookworm infections were identified in all the age groups with highest infection $2(40.0 \%$ ) occurring in the age group 3-16 years and the least 4(8.0\%) in the 5-8 age group. Ascaris and Trichuris infections were observed in the age groups 58 years and 9-12 years. Strongyloides and Taenia infections were observed in the age group of 9-12 years only. Schistosoma infections were observed in children aged 9-12 and 13-16 years but not in those aged 58 years. Hookworm and Ascaris infections were predominant in the group 5-8 years and 912 years age groups while Hookworm and Schistosoma were the only helminth infection observed in the age group 1316years.

Table 1: Prevalence of geohelminth in the schools

\begin{tabular}{|ccccccccc|}
\hline $\begin{array}{c}\text { Name of } \\
\text { School }\end{array}$ & $\begin{array}{c}\text { No. } \\
\text { examined }\end{array}$ & $\begin{array}{c}\text { Hookworm } \\
\text { no. +ve(\%) }\end{array}$ & $\begin{array}{c}\text { Ascaris } \\
\text { no.+ve(\%) }\end{array}$ & $\begin{array}{c}\text { Strongyloides } \\
\text { No. +ve(\%) }\end{array}$ & $\begin{array}{c}\text { Trichuris } \\
\text { trichiura } \\
\text { no.+ve(\%) }\end{array}$ & $\begin{array}{c}\text { Taenia } \\
\text { no.+ve(\%) }\end{array}$ & $\begin{array}{c}\text { Schistosoma } \\
\text { no +ve(\%) }\end{array}$ & $\begin{array}{c}\text { Total } \\
(\%)\end{array}$ \\
$\begin{array}{c}\text { Ugwu- } \\
\text { Oye }\end{array}$ & 30 & $4(13.3)$ & $2(6.66)$ & - & $1(3.33)$ & - & $1(3.33)$ & $8(26.7)$ \\
St. Joseph & 30 & $2(6.66)$ & $1(3.33)$ & - & - & & - & - \\
Egbengwu & 30 & $6(20)$ & $1(3.33)$ & $1(3.33)$ & $1(3.33)$ & - & $1(3.33)$ & $10(33.3)$ \\
Unity & 30 & $1(3.33)$ & $3(10)$ & - & - & $1(3.33)$ & - & $5(16.7)$ \\
Total & 120 & $13(50.0)$ & $7(26.9)$ & $1(3.84)$ & $2(7.69)$ & $1(3.84)$ & $2 .(7.69)$ & $26(21.7)$ \\
\hline
\end{tabular}

Table 2: Sex specific prevalence of the geohelminth parasites among the pupils

\begin{tabular}{|c|c|c|c|c|c|c|c|c|}
\hline Sex & $\begin{array}{c}\text { No } \\
\text { examined }\end{array}$ & $\begin{array}{c}\text { Hookworm } \\
\text { no +ve(\%) }\end{array}$ & $\begin{array}{c}\text { Ascaris } \\
\text { no.+ve( }(\%)\end{array}$ & $\begin{array}{c}\text { Strongyiodes } \\
\text { no +ve }(\%)\end{array}$ & $\begin{array}{c}\text { Trichuris } \\
\text { no.+ve(\%) }\end{array}$ & $\begin{array}{c}\text { Taenia } \\
\text { no.+ve( }(\%)\end{array}$ & $\begin{array}{c}\text { Schistosome } \\
\text { no.+ve }(\%)\end{array}$ & $\begin{array}{l}\text { Total } \\
(\%)\end{array}$ \\
\hline Male & 60 & $6(10)$ & $4(6.66)$ & - & $1(1.66)$ & - & 1(1.66) & $12(20)$ \\
\hline Female & 60 & $7(11.7)$ & $3(5)$ & $1(1.66)$ & 1(1.66) & $1(6.66)$ & $1(1.66)$ & $14(23.3)$ \\
\hline Total & 120 & $13(10.8)$ & $7(5.83)$ & $1(0.83)$ & $2(1.66)$ & $1(0.83)$ & $2(1.66)$ & $26(21.7)$ \\
\hline
\end{tabular}


Table 3: Age-specific prevalence of different geohelminth species among the pupils of different age groups

\begin{tabular}{|ccccccccc|}
\hline $\begin{array}{l}\text { Age unit } \\
\text { (years) }\end{array}$ & $\begin{array}{l}\text { No } \\
\text { examine }\end{array}$ & $\begin{array}{l}\text { Hookworm } \\
\text { no. +ve(\%) }\end{array}$ & $\begin{array}{l}\text { Ascaris } \\
\text { no+ve(\%) }\end{array}$ & $\begin{array}{l}\text { Strongyiodes } \\
\text { no. +ve(\%) }\end{array}$ & $\begin{array}{l}\text { Trichuris } \\
\text { no+ve(\%) }\end{array}$ & $\begin{array}{l}\text { Taenia } \\
\text { no.+ve( } \\
\%)\end{array}$ & $\begin{array}{l}\text { Schistosome } \\
\text { no+ve(\%) }\end{array}$ & $\begin{array}{l}\text { Total } \\
\text { no+ve(\%) }\end{array}$ \\
$5-8$ & 50 & $4(8)$ & $3(6)$ & - & $1(2)$ & - & - & $8(16)$ \\
$9-12$ & 65 & $7(10.8)$ & $4(6.15)$ & $1(1.53)$ & $1(1.53)$ & $1(153)$ & $1(1.53)$ & $15(23.1)$ \\
$13-16$ & 5 & $2(40)$ & - & - & - & - & $1(20)$ & $3(60)$ \\
total & 120 & $13(10.8)$ & $7(5.83)$ & $1(0.83)$ & $2(1.66)$ & $1(0.83)$ & $2(1.66)$ & $26(21.7)$ \\
\hline
\end{tabular}

\section{Discussion}

The study showed an overall prevalence of 26(21.7\%) among the primary school children in Nimo Community, Njikoka Local Government Area, Anambra State, Nigeria. This result agrees with that of [11] who observed $22.8 \%$ prevalence of intestinal parasites in Bareilly District, Uttar Predesh India, but disagrees with those of [12] and [13] who observed 55.3\% and 58.5\%, in parts of Niger Delta and Benue States of Nigeria respectively. The lower percentage in the study could be due to a combination of factors like improved hygiene, communal control efforts and regular deworming of children by parents and guardians.

The common intestinal parasites isolated in this study, Ascaris lumbricoides, Hookworm spp, Strongyloides stercoralis, Trichuris trichiura, Taenia spp, and Schistosma mansoni are in no way different from those reported by other researchers in other parts of the country. [14] recorded that Ascaris, Hookworm and Trichuris infections are common throughout Nigeria. Taenia species maintained a low prevalence among the school pupils because beef and pork are not regular part of their diet, so they stand lesser chance of exposure to Taeniasis. Schistosoma mansoni was seen in two children, they must have acquired the infections from going to the stream where the snail intermediate host is found [15].

Hookworm has the highest prevalence of 13(10.8\%) followed by Ascaris lumbircoides 7(5.83\%). The high prevalence of Hookworm shows that the study population still practice indiscriminate and open defecation most often in the same spot. This practice in an area with warm humid climate encourages rapid development of infective stages. Because most of the children walk, play, run errands, fetch water and do most out-door things without putting on foot wears, they can easily be infected. This is in tandem with the result of studies conducted in other areas in Nigeria by [12],[13],[16],[17] in which Hookworm infection rated highest among other infections. Nimo has a suburban village environment where some of the children in the rural areas go to farm on bare foot thereby exposing themselves to the infective stage larva (L3) infection of Hookworm and Strongyloides.

The prevalence of Ascaris lumbricoides in the study indicates high level of contamination of the environment with human and animal faecal matter which enhances transmission in the community. Most of the children especially those in government schools defecate in nearby bushes around their schools. This shows poor supervision of the children in these government schools and explains the high prevalence obtained from them 18(30.0\%), while the private schools with fairly hygienic environment had low prevalence of 8(13.3\%). Children in the ages 9-12 years were mostly infected because within this age bracket, little or no care is given to the children by their parent or guardians. The children are able to do most things on their own, they move about on their own, do little house chores, fetch water and because they are not old enough to understand the need of general cleanliness, they tend to be careless about personal hygiene. The children within the age group 5-8 years are usually under supervision, so their route of infection is usually through hand soiling while playing on the sand. The age group 13-16 years are older children, some of them are conscious of putting on footwear, washing their hands after defaecating. This is in line with the studies of [18] who revealed that Ascaris lumbricoides infection increased sharply from less than 6 months old, and reaches its peak at 6-15years. Some children pick up fruits in the farm and eat without washing them, they even eat food without washing' off soil from their hands and they are the people that mostly practice indiscriminate defecation, so they run higher risk of infection.

Most homes lack pit-latrines and so use bushes around the house as alternative for defaection. This observation corresponds with the study by [18] and [19] that poor hygiene is one of the factors that increases risk of infections. This could be due to ignorance and lack of proper education on the epidemiology of worm infection. Most children walk about bare-footed at home and go to school in the same manner because their parents cannot afford foot wears for them. [18] also showed that socioeconomic factors also account for the nature of infection.

The prevalence of intestinal helminth infections among the pupils is relatively low but it is still of public health importance. The pupils as well as the community at large should not depend entirely on the use of anthihelminthic drugs only but should incorporate proper environmental and personal hygiene. They should be educated on the dangers of indiscriminate defaecation in their surroundings. Proper disposal of human and animal excreta should be encouraged to reduce contamination of the environment and reduction of helminth infection.

\section{References}

[1].W.H.O(2002). Prevention and control of soil Transmitted helminthiasis. Report of WHO Expert Committee, Geneva.WHO Report Series No. 912

[2].J. Steketee (2003) Pregnancy, Nutrition and Parasitic Diseases. Nutr.vol. 133 no. 5 1661S-1667S

[3].W.H.O(1987). Prevention and Control of intestinal parasitic infection WHO Technical Report Series, 749.

[4].H.L Fashuyi (1983). The prevalence of helminth eggs in human faeces deposited on the street of Lagos. West African Medical Journal, 1(2): 135-137pp. 
[5].O.E Okon and E.E Oku (2001). Prevalence of intestinal parasites among school children in two contrasting communities in Cross River State, Nigeria. Nigerian Journal of Parasitology,22: 1 15-120pp.

[6].C.I Eneanya and V.S Njom (2003). Geohelminth contamination of some common fruits and vegetables in Enugu, Southeast Nigeria. The Nig. J. Parasitol., 24: 123-128.

[7].L.S Stephenson (1994). Helminth parasites, a major factor in malnutrition. WHO forum, 15: 169-72pp.

[8].NPC (2006) National population commission Nigeria census 2006.

[9].J. King (1984). Basic Laboratory Methods in Medical Parasitology. Bull World Health. 74:22-25.

[10]. M. Cheesbrough (1992). Medical Laboratory Manual for Tropical Countries. $2^{\text {nd }}$ edition, University press, Cambridge. 200-357.

[11]. M.K Rashid, M. Joshi, H.S Joshi and K. Fatemi (2011). Prevalence of intestinal parasites among school going children in Bareilhy District. NJIRM, 2(1), 35-38pp.

[12]. E.C Amadi, A. Ebenizer and O. Azuonwu (2010): The influence of community ecology and behavior on the bionomics of intestinal helminthiasis in parts of Niger Delta, Nigeria. Nigerian Journal of Parasitology. ISSN 1117 4145 volume $31(2): 79-83$.

[13]. R.S Houmsou, E.U Amuta and T.A Olusi (2010). Prevalence of intestinal parasites among primary school children in Markurdi, Benue State, Nigeria. The internet Journal of Infections Disease.1:4-7

[14]. K.N Opara, E.A Nwoke, C.O Abanobi, C.O.E Onwuliri, C. Iwuala and A.N Amadi (2010). Prevalence of intestinal parasites among children in day-care centres in Owerri Metropolis, Nigeria. The Nig. J. of parasitology. (Abstracts) 16.

[15]. D.R Arora and B.B Arora (2010). Medical Parasitology. SDR printers, Delhi-110094.ISBN:978-81-1850-1. pp123173.

[16]. R.C Nwaizugbo and C.M.U Ajero (2007). Intestinal parasites in feaces deposited indiscriminately around Owerri Municipal Council of Imo State, Nigeria. Nig. J. of Parasitology (Abstracts) 22pp.

[17]. J.I Mbanugo and S.O Enemuo (2002). A preliminary survey of intestinal parasites in primary school children in Anaocha L.G.A. Anambra State, Nigeria. Nig .J. Of Parasitology. 23:51-57.

[18]. A.B.C Nwosu (1981). The community ecology of soil hyperendemic area of Southern Nigeria. Ann. Trop. Med. Parasit. 75:1972O3pp.

[19]. A.B Ohaegbula (1996). Prevalence of gastro-intestinal parasites in two contrasting communities in Enugu, Nigeria. Nig, J. of Parasitology 17:95-98. 